\title{
A Preliminary Study on the Difference in Growth of Brassica chinensis L. var. parachinensis Treated with Different Composted Chicken Manure
}

\author{
J.L. Tan ${ }^{1 *}$, K.Y. Ang ${ }^{1}$, M.H. Chow ${ }^{1}$, E.T.Y. Lee ${ }^{1}$, K.H. Lee ${ }^{1}$, L.Y. Lee1, S.W. Ooi ${ }^{1}$, W.C. Soh ${ }^{1}$ and \\ R. Sithambaram ${ }^{1}$
}

${ }^{1}$ Department of Agricultural and Food Science, Faculty of Science, Universiti Tunku Abdul Rahman, Perak, Malaysia

\begin{abstract}
Chicken manure is one of the popular organic fertilizers used in vegetable farming in Malaysia. Chicken manure is divided into two types, namely broiler chicken manure (BCM) and layer chicken manure (LCM). The effectiveness of these chicken manures is often questionable due to the different method of raising broilers and layers. Therefore, the present study was carried out to determine the effect of the broiler and layer chicken manures on the growth of choy sum (Brassica chinensis L. var. parachinensis), a common farmed leafy vegetable in the country. This study was carried out in the Agricultural Park of Universiti Tunku Abdul Rahman (Perak Campus), Malaysia from February to May 2019. Randomized Complete Block Design (RCBD) methods were used in this study. The chicken manures were composted for roughly 2 months before the experiment. There was no significant difference in the dry weight, plant height and root length of the choy sum treated with either BCM or LCM. Although the choy sum treated with BCM has a higher fresh weight (177.53 g) as compared to that of LCM (134.64 g), this may be due to the natural fluctuation of water content within the plants. Therefore, the results of the present study show that both the chicken manure has a similar effect on the growth of choy sum. The authors recommend further studies on the chemical composition and optimization of chicken manure application in enhancing the growth and yields of leafy vegetables.
\end{abstract}

Keywords: composted chicken manure; broiler and layer chicken manure; organic fertilizer; vegetables

\section{INTRODUCTION}

Chicken manure is one of the popular organic fertilizers used in vegetable farming in Malaysia (Food and Agriculture Organization, 2004). According to Tan (2018), chicken manure is the preferred fertilizers for most farmers in Cameron Highlands, Malaysia. The popularity of chicken manure can be attributed to its high macronutrient contents (Basri et al., 2013) as well as increasing supply due to the rapid expansion of the chicken farming in Malaysia (Arifin et al., 2006). The application of chicken manure as fertilizer is also a means of recycling the waste. Chicken manure is generally divided into two types, namely broiler chicken manure (BCM) and layer chicken manure (LCM). The effectiveness of these two chicken manures is often questioned by farmers and agriculturists due to the different methods used in raising the chickens. For instance, the nutrient composition of chicken feed for broilers is to stimulate rapid expansion rate while for layers is to stimulate egg laying (Reddy, 2019). As such, the effect of these chicken manures on the growth of vegetables is not well tested. Therefore, the present study was carried out to determine the effect of the broiler and layer chicken manures on the growth of a representative leafy vegetable, choy sum (Brassica chinensis L. var. parachinensis). Choy Sum is one of the widely grown leafy vegetables in Malaysia (Tin et al., 2000). The per capita consumption of choy sum in Malaysia increases tremendously from $3.76 \mathrm{~kg}$ in 1982 to $8.46 \mathrm{~kg}$ in 
2001, which indicate the high demand of this vegetable (Tey et al., 2009). The results of this study will provide better insights to vegetable farmers on the use of these chicken manures, and indirectly the management of manure wastes in layer and broiler farms.

\section{MATERIALS AND METHODS}

\section{A. Experimental Site}

The research was carried out at the Agricultural Park (N 4 ${ }^{\circ} 20$ '31.02072", E 101 '8'24.5454”) of Universiti Tunku Abdul Rahman, Perak Campus in Kampar, Malaysia from February 2019 to May 2019. The altitude of the Agriculture Park is $118.49 \mathrm{~m}$ above sea level. The mean temperature in Kampar area is $27.3^{\circ} \mathrm{C}$ and the average annual rainfall is $3133 \mathrm{~mm}$ (Merkel, 2015). The soil type of the planting area is sandy clay.

\section{B. Preparation of Compost Chicken Manure}

The manures from broiler and layer chickens were sourced from Malacca, Malaysia and were separately piled outside, about 20 meters apart and covered with black garden net. Both chicken manures were turned daily to encourage aeration. Water was added, whenever the chicken manure was dry, for microbial growth and activity. The composted broiler chicken manure (BCM) and composted layer chicken manure (LCM) was ready after 2 months (6o days) with soillike texture and no foul odour.

\section{Experimental Design}

The experiment consisted of two treatments (i.e., broiler chicken manure and layer chicken manure) and one control. Nine planting beds with the size of $0.6 \mathrm{~m}^{2}$ each were raised in a Randomized Complete Block Design (RCBD) with three replications for each treatment (Figure 1) (Yeshiwas et al., 2018). The experimental controls were not provided with any fertilizer. Chicken manure treatments were applied at the rate of $1500 \mathrm{~kg} / 4046 \mathrm{~m}^{2}$ (3707kg/ ha) per application, following the local farmer practice. The first application of composted chicken manure was done on the sowing day and the following applications were done every 7 days. Broadcasting was used when applying the chicken manure to the plots. Chicken manure was the only source of fertilizer used in this study.

\section{Planting}

Commercial choy sum seed (Leckat, oo8 Wang Bujang, China) were purchased from a local agricultural shop. Direct seeding was used to avoid transplanting shock (Masarirambi et al., 2012). Each treatment plot was sowed with approximately $15.0 \mathrm{~g}$ of seed (approximately $500 \mathrm{seed} / \mathrm{g}$ ) by broadcasting technique. The tiny seed were mixed with sand before being broadcasted to encourage uniform distribution in the soil (Masarirambi et al., 2012). After 14 days of sowing, seedlings were thinned out to allow appropriate spacing between plants for their growth. Overhead water sprinklers were used for irrigation, which was carried out to encourage uniform germination as well as to provide sufficient water for plant growth. Irrigation was carried out daily, and it was skipped if there was sufficient rain. Weeds were controlled by hand weeding every 3 days to avoid nutrients competition with the crop.

\section{E. Data Collection}

The fresh weight, dry weight, plant height and root length were measured to assess the response of choy sum (Brassica chinensis L. var. parachinensis) to the treatments of BCM and LCM. Twenty (20) plants from each plot were sampled at random after 30 days of planting to obtain the average of the measurements. The fresh weight was measured immediately after sampling using a portable electronic balance (Camry, EI-O2HS, China). The plant height and root length were measured using an Auora ${ }^{\circledR}$ plastic ruler. The plant samples were put into a drying oven (Memmert, MMT-IN110, Germany) at $40^{\circ} \mathrm{C}$ for $48 \mathrm{~h}$ before measuring the dry weight using a laboratory electronic balance (Mettler Toledo, ME1002, Switzerland).

IBM Statistical Package for the Social Sciences (SPSS) version 23.0 was used in the analysis of the data. The collected data were subjected to one-way analysis of variance (ANOVA) and post-hoc test (Tukey HSD). Prior to ANOVA, the assumption of normality was evaluated using ShapiroWilks (S-W) W-tests. If the assumption of normality is violated $(\mathrm{P}<0.05)$, non-parametric test Kruskal-Wallis $\mathrm{H}-$ test was used as an alternative to one-way ANOVA. The Mann-Whitney $U$-test was used as a post-hoc test for Kruskal-Wallis H test (Tan, 2012). 


\begin{tabular}{|l|l|l|l|}
\hline Blocks & \multicolumn{3}{|c|}{ Treatments } \\
\hline 1 & Control & Broiler manure & Layer manure \\
\hline 2 & Layer manure & Control & Broiler manure \\
\hline 3 & Broiler manure & Layer manure & Control \\
\hline
\end{tabular}

Figure 1. Layout of the treatments in a randomized complete block design (RCBD)

\section{RESULTS AND DISCUSSION}

The assumption of normality for fresh weight, dry weight, plant height and root length were evaluated using the Shapiro-Wilk (S-W) W-test, of which none of the data violate the assumption of normality ( $\mathrm{P}>0.05$ ). Therefore, one-way ANOVA was used to test for significant difference $(\mathrm{P}<0.05)$ for each of the parameters. The one-way ANOVA (Table 1) shows that the fresh weight, dry weight and plant height of choy sum treated with BCM and LCM were significantly higher $(\mathrm{P}<0.05)$ than the control. However, these treatments have no significant effect on the root length. According to Table 1, the use of BCM resulted in a significantly higher fresh weight of the choy sum as compared to LCM. However, both treatments did not exert any significant effects on the dry weight and plant height.

It is known that there is no necessity for a plant to develop extensive root systems if the nutrient supply is sufficient (Eghball \& Maranville, 1993; Robinson \& Rorison, 1983). Based on Table 1, the mean root length of the choy sum treated with composted BCM was only slightly longer than composted LCM. The slight difference may be due to nutrient availability within soil microenvironments. For example, Wang et al. (2008) reported that the presence of nitrate may result in root growth because of its role as a signalling substance. The rooting effects are unlikely to be caused by the two different composted chicken manure, as Mkhabela (2004) reported that the inorganic nitrogen, such as ammonia and nitrate, are almost similar in both manure.

The composted manure treatments show a significant effect on the fresh weight, dry weight and plant height of the choy sum (Table 1). The Tukey HSD test shows that there is no difference in dry weight and plant height for the sample treated with composted BCM and LCM. The choy sum of the control was significantly lighter and shorter than those treated with the composted manure. Therefore, this indicated that the choy sum samples responded positively to the nutrients provided by the manure. According to Mkhabela (2004), the nitrogen (N) and potassium (K) content of broiler and layer manure are similar while broiler has higher phosphorus (P). The total NPK value of the BCM were 29.0 $\mathrm{kg} / \mathrm{t}, 12.9 \mathrm{~kg} / \mathrm{t}$ and $12.5 \mathrm{~kg} / \mathrm{t}$ respectively, whereas LCM were $30.5 \mathrm{~kg} / \mathrm{t}, 9.6 \mathrm{~kg} / \mathrm{t}$ and $11.3 \mathrm{~kg} / \mathrm{t}$ respectively. Rubeiz et al. (1993) reported that BCM contained 4.46\% N and 2.19\%P, while LCM contained $3.84 \% \mathrm{~N}$ and $3.14 \% \mathrm{P}$. The BCM has slightly higher $\mathrm{N}$ and lower $\mathrm{P}$ content as compared to LCM. According to Chastain et al. (2004), one of the factors contribute to the difference were the nutrient composition of the chicken feed. In spite of this, the result obtained in this study shows that the choy sum samples treated with either composted BCM or LCM displayed no significant difference in terms of height and dry weight. Therefore, both the chicken manures may have been providing a similar amount of nutrients for the growth of choy sum as dry weight considers the amount of protoplasm and dry matter, excluding water (Vince et al., 2011).

On the other hand, choy sum treated with composted BCM recorded a higher fresh weight which indicated that they retained more water (Table 1). According to Vince et al. (2011), the water content in plants fluctuate based on the moisture in the surrounding environment, hence fresh weight is not always reliable. The most likely reason for the differences in fresh weight in this study is the soil type in the planting area. As the study was conducted in an open field, therefore, the soil type in the nine constructed planting beds may vary from each other in terms of water retention. The soil type of the planting area is sandy clay, where some area may have more clay than others resulting in higher water retention capacity. The effect of irrigation on the fresh weight of the sampled choy sum is likely minimal as an overhead water sprinkler system is used and all plants were supplied with sufficient water. Considering the present study was only tested on a pilot scale, it may be worthwhile to look into the 
composition and effects of composted BCM and LCM on a larger scale. This is especially considering that vegetables mostly sold based on their fresh weight.

Furthermore, the application rate of chicken manure in current local farmer practice were quite high (approximately 3.7 ton/ha), and this rate is decided based on personal experience or recommendation from other farmers. The optimal amount of composted chicken manure to achieve optimal nutrient use efficiency is not known and thus should be studied. For instance, chicken manure if properly managed is a sustainable agriculture option, where less leaching of nitrate was reported in treated soil. Other benefits includes reduce erosion, diversify agroecosystem, better soil water-holding capacity, and better infiltration (Hoover et al., 2019). However, the overapplication of chicken manure may lead to environmental issue, such as accumulation of phosphate (PO4-P) in the soil and leaching of phosphate into waterbody which may lead to eutrophication (Hoover et al., 2015).

According to the result, both types of chicken manure does not exhibit significant difference in plant growth, therefore, farmers are recommended to consider using either type of chicken manure depending on local availability. This can assist in the recycling of waste in local poultry industry as well as lowering cost of transporting the waste. In turn, helping farmers to lower the cost of production. In addition, farmers are also recommended to compost the chicken manure before applying them. Composting of chicken manure will help to remove foul odour, lower salinity of the manure as well as suppression of harmful human pathogen, such as Salmonella spp. (Cayci et. al., 2017; Chen \& Jiang, 2014).

Table 1: The mean fresh weight, dry weight, plant height and root length of choy sum after 30 days.

\begin{tabular}{lrrrr}
\hline Treatment & Fresh Weight $(\mathrm{g})$ & Dry Weight $(\mathrm{g})$ & Plant Height $(\mathbf{c m})$ & Root Length (cm) \\
\hline Control & $33.17 \pm 16.22^{\mathrm{a}}$ & $6.56 \pm 2.73^{\mathrm{a}}$ & $5.46 \pm 2.92^{\mathrm{a}}$ & $4.27 \pm 0.77^{\mathrm{a}}$ \\
BCM & $177.53 \pm 24.43^{\mathrm{b}}$ & $20.80 \pm 4.03^{\mathrm{b}}$ & $11.96 \pm 3.37^{\mathrm{b}}$ & $6.61 \pm 3.52^{\mathrm{a}}$ \\
LCM & $134.67 \pm 28.66^{\mathrm{c}}$ & $17.28 \pm 4.11^{\mathrm{b}}$ & $12.23 \pm 3.99^{\mathrm{b}}$ & $5.51 \pm 1.59^{\mathrm{a}}$
\end{tabular}

Note: control: no input; BCM: composted broiler chicken manure; LCM: composted layer chicken manure. The different superscript alphabets indicate a significant difference in Tukey HSD within the same column.

\section{CONCLUSION}

The application of composted BCM and LCM shows no significant difference $(\mathrm{P}<0.05)$ on the dry weight, plant height and root length of choy sum (Brassica chinensis L. var. parachinensis). The fresh weight of the choy sum treated with BCM was significantly higher than the sample treated with LCM. However, the fresh weight is not a reliable indicator because the water content fluctuates in vegetables. Therefore, based on the dry weight and plant height, it can be postulated that the growth of choy sum is similar for both chicken manures. Further study on the chemical composition and optimization of application rate for both types of chicken manure is recommended. As recommendations to the farmers, both types of chicken manure exhibit similar effect on plant growth and suggested to use either one depending on local availability. In addition, farmers are recommended to compost the chicken manure before applying.

\section{ACKNOWLEDGEMENT}

The authors acknowledge the support from the Faculty of Science, Universiti Tunku Abdul Rahman, Malaysia. This project was supported by the Department of Agricultural and Food Science, Faculty of Science, Universiti Tunku Abdul Rahman, Malaysia. 


\section{REFERENCES}

Arifin, B, Bono, A \& Janaun, J 2006, 'The transformation of chicken manure into mineralized organic fertilizer', Journal of Sustainability Science and Management, vol. 1, no. 1, pp. 58-63.

Basri, MHA, Abdu, A, Jusop, S, Ahmed, OH, Abdul-Hamid, H, Kusno, M-A, Zainal, B, Senin, AL \& Junejo, N 2013, 'Effects of mixed organic and inorganic fertilizers application on soil properties and the growth of kenaf (Hibiscus cannabinus L.) cultivated on bris soil', American Journal of Applied Sciences, vol. 10, no. 12, pp. 1586-1597.

Cayci, G, Temiz, C \& Ok, SS 2017, 'The effects of fresh and composted chicken manures on some soil characteristics', Communications in Soil Science and Plant Analysis, vol. 48, no. 1, pp. 1-11.

Chastain, JP, Camberato, JJ \& Skewes, P 2004, Poultry manure production and nutrient content, viewed 5 February

2021,

<https://www.clemson.edu/extension/camm/manuals/p oultry/pch3b_oo.pdf>.

Chen, Z \& Jiang, X 2014, 'Microbiological safety of chicken litter or chicken litter-based organic fertilizers: a review', Agriculture, vol. 4, pp. 1-29.

Eghball, B \& Maranville, JW 1993, 'Root development and nitrogen influx of corn genotypes grown under combined drought and N stress.', Agronomy Journal, vol. 85, pp. 147152.

Food and Agriculture Organization 2004, Fertilizer use by crop in Malaysia, Rome, Italy, Food and Agriculture Organization of the United Nation.

Hoover, NL, Kanwar, R, Soupir, M \& Pederson, C 2015, 'Effects of poultry manure application on phosphorus in soil and tile drain water under a corn-soybean rotation', Water, Air and Soil Pollution, vol. 226, no. 138, pp. 1-12.

Hoover, NL, Law, JY, Long, LAM, Kanwar, RS \& Soupir, ML 2019, 'Long-term impact of poultry manure on crop yield, soil and water quality, and crop revenue', Journal of Environmental Management, vol. 252, pp. 1-11.

Masarirambi, M, Sibandze, N, Wahome, PK \& Oseni, T 2012, 'Effects of kraal manure application rates on growth and yield of wild okra (Corchorus olitorius L.) in a sub-tropical environment', Asian Journal of Agricultural Science, vol. 4, no. 1 , pp. 89-95.
Merkel, A 2015. Kampar Climate, Climate-Data.org, viewed 10 July 2019, <https://en.climatedata.org/asia/malaysia/perak/kampar-25987/>.

Mkhabela, TS 2004, 'Substitution of fertilizer with poultry manure: is this economically viable?.', Agrekon, vol. 43, no. 3 , pp. $347-356$.

Reddy, J 2019, Chicken Feeding Guide for Layers and Broilers, viewed 5 February 2021, <https://www.agrifarming.in/chicken-feeding-guide-forlayers-and-broilers $>$.

Robinson, D \& Rorison, IH 1983, 'Relationship between root morphology and nitrogen availability in a recent theoretical model describing nitrogen uptake from soil', Plant, Cell \& Environment, vol. 6, pp. 641-647.

Rubeiz, IG, Sabra, AS, Al-Assir, IA \& Farran, MT 1993, 'Layer and broiler poultry manure as nitrogen fertilizer sources for cabbage production', Communications in Soil Science and Plant Analysis, vol. 24, no. 13-14, pp. 1583-1589.

Tan, JL 2012, 'Biodiversity of shrimps in ex-tin mining ponds around Kampar, Perak', Bachelor Thesis, Universiti Tunku Abdul Rahman, Perak, Malaysia.

Tan, JL 2018, 'Identification and Management of Thrips on Solanaceous Plants in Cameron Highlands', Master Thesis, Universiti Tunku Abdul Rahman.

Tey, YS, Shamsudin, MN, Radam, A, Mohamed, Z, Selamat, J \& Ramin, AG 2009, 'Demand for vegetables in Malaysia', Journal of Agribusiness Marketing, vol. 2, pp. 54-67.

Tin, KP, Keng, H \& Avadhani, PN 2000, A guide to common vegetables, Singapore, Science Centre.

Vince, O, Zoltan, M, Egyetem, D, Egyetem, N-M \& Egyetem, P 2011, Plant Physiology - Overview of plant growth and development, viewed 18 July 2019, <https://www.tankonyvtar.hu/en/tartalom/tamop425/oo 10_1A_Book_angol_01_novenyelettan/cho4so2.html >.

Wang, ZR, Rui, YK, Shen, JB \& Zhang, FS 2008, 'Effects of N fertilizer on root growth in Zea mays L. seedlings', Spanish Journal of Agricultural Research, vol. 6, no. 4, pp. 677-682. Yeshiwas, Y, Zewdie, BYB, Chekol, A \& Walle, A 2018, 'Effect of nitrogen fertilizer and farmyard manure on growth and yield of lettuce (Lactuca sativa L.)', International Journal of Agricultural Research, vol. 13, pp. 74-79. 